The American Journal of Social Science and Education Innovations

(ISSN - 2689-100x)

VOLUME 04 ISSUE 01 Pages: 9-13

SJIF IMPACT FACTOR (2020: 5. 525) (2021: 5 . 857)

OCLC - 1121105668 METADATA IF - 8.106

Crossref doi gr Google (2)

Research Article

\title{
DEVELOPMENT OF UZBEK SCULPTURE DURING THE YEARS OF INDEPENDENCE AND NEW TRENDS
}

\author{
Submission Date: December 27, 2021, Accepted Date: January 07, 2022, \\ Published Date: January 18, 2022 | \\ Crossref doi: https://doi.org/10.37547/tajssei/Volume04lssue01-03
}

rnals.com/index.php/ta

jssei

Copyright: Original content from this work may be used under the terms of the creative commons attributes 4.0 licence.

Azat Amatovich Yusupov

Associate Professor, National Institute of Arts and Design named after Kamoliddin Bekhzod, Tashkent, Uzbekistan

\section{ABSTRACT}

The article describes the interpretation of the works of famous Uzbek sculptors, mainly in the field of monumental sculpture and national artistic features of the works created by them during the period of independence. The tendencies of the development of Uzbek sculpture in the direction of realism, the criteria of modern Uzbek sculpture, their artistic and aesthetic features are described.

\section{KEYWORDS}

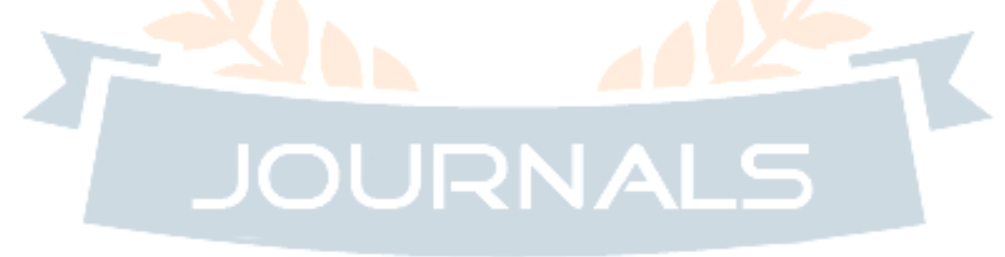

Sculpture, modeling, plastic, easel sculpture, monumental sculpture, relief, bas-relief, high relief, counter-relief, memorial complexes.

\section{INTRODUCTION}

Within the framework of the positive influence of independence, the path was opened for free creativity in various directions and styles of art. Including sculpture. As a result, monumental sculptures, like paintings, have become leaders in the modern artistic process. 
The American Journal of Social Science and Education Innovations (ISSN - 2689-100x)

VOLUME 04 ISSUE 01 Pages: 9-13

SJIF IMPACT FACTOR (2020: 5. 525) (2021: 5. 857)

OCLC - 1121105668 METADATA IF - 8.106

\section{Crossref
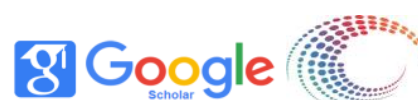 \\ metapenta \\ (5) WorldCat"}

Publisher: The USA Journals

As a result of Uzbekistan's gaining independence, a new era has begun in the field of fine arts and sculpture. The creation of the Academy of Arts of Uzbekistan in 1997 by the decree of the first President of the Republic of Uzbekistan Islam Abduganievich Karimov opened a new stage in the development of culture. It is important to note that as a result of the abolition of ideological control in art, artists who received creative freedom began to create works in stylistic diversity. And the creation of the Academy of Arts of Uzbekistan accelerated this process.

Over the years of independence, creative freedom has led to the development of various styles and trends in art. The criterion for evaluating art began to be determined by the artist's personal thoughts and experiences. The formation of new spiritual and ideological directions in Uzbekistan, in turn, had an effective impact on all areas of contemporary art, expanding the scope of creative searches and further accelerating the development of artistic thinking.

\section{THE MAIN FINDINGS AND RESULTS}

The idea of redefining a wide range of historical, cultural, spiritual and moral values, the principles of renewal were clearly reflected in the field of architecture, fine and applied decor, music and entertainment art, fiction and documentary films, as well as the television broadcasting system.

Although art, especially sculpture, as an integral part of the ideological and spiritual world, did not react as quickly as advertising as a means of agitation and propaganda to political, social and economic changes in the life of the nation, in sculptures, created during the years of independence, the influence of the new ideological environment, the predominance of national and historical themes was reflected, and large art monuments were erected.
At the same time, the era of globalization opened up wide opportunities for expanding international cultural ties, and Uzbek artists had the opportunity to get acquainted with the artistic heritage of the whole world, as well as creative searches for sculptors. The rapid growth of urban planning, the search for new architectural solutions that combine various types of art, led to the development of a new field of design and showed the relevance of sculpture, and the fact that it is the most basic artistic element. The spatiality, size, originality of the idea, the constructiveness of the sculpture being created, postmodern art has reached its aesthetic peak, involving contemporary Uzbek artists. Such sculptors as I. Jabborov, J. Mirtojiev, A. Rakhmatullaev, L. Ryabtsev, K. Norkhurozov, P. Podosinnikov, M. Aliyev and others have revealed in their works new thematic ideas of glorification of our national historical past.

In the development of the art of sculpture in the country, tremendous changes can be traced. Famous Uzbek sculptors create statues of prominent historical figures and scientists abroad. Monumental statues are being erected in various regions and cities of our country.

The art of sculpture is developing so much that Uzbek sculptors are becoming famous all over the world for their art and craftsmanship. This can be proved by the fact that Uzbek sculptors have created and erected monuments to our great ancestors, scientists, in a number of leading countries, such as Belgium, Japan, Azerbaijan and others.

During the years of independence, attention to monumental sculpture has increased. The prestige of the art of monumental sculpture is growing, especially due to the creation of images, heroes, statesmen, and especially people close to our people who have made 
The American Journal of Social Science and Education Innovations (ISSN - 2689-100x)

VOLUME 04 ISSUE 01 Pages: 9-13

SJIF IMPACT FACTOR (2020: 5. 525) (2021: 5. 857)

OCLC - 1121105668 METADATA IF - 8.106

\section{Crossref
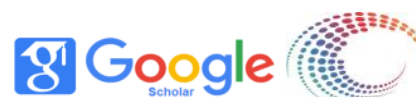 \\ METลDกTด \\ (5) WorldCat"}

Publisher: The USA Journals

a significant contribution to the development of the country and the well-being of the people.

Another positive aspect of monumental sculpture in the years of independence is that for the first time in these years, large-scale sculptures were created on themes that have not been mentioned for a long time and were banned. Now monuments to great commanders and national heroes of the past, victims of repression have been created and erected by Uzbek sculptors in all corners of the country.

As evidence for the above words, we can cite the works of monumental sculpture, created in honor of the great poet and thinker, statesman Mir Alisher Navoi, ruler and poet Zakhiriddin Muhammad Babur, founder of the school of oriental miniatures Kamoliddin Behzod, expert in the science of astrology Al Fergani, great ruler Amir Temur, national hero of our country Jaloliddin Manguberdy and other famous figures.

Usually, monumental statues are erected to perpetuate the memory of important historical events and famous personalities. Usually the content of monumental sculpture is directly related to the environment. This requires that the monumental sculpture is in harmony with neighboring architectural structures and nature. Thus, the sculpture lends more grandeur and has an impact on the environment. For example, you can see and admire several such majestic statues in the centers of different cities and regions of our republic.

The uniqueness of Ilkhom Jabborov's compositions is evident in the works he created. In recent years, unique sculptures began to appear in the work of Ilkhom Jabborov. The sculptor managed to create unique images of a number of scientists and historical figures. Among them, it should be especially noted such works of sculpture as "Ibn Sino”, "Farobi”, “Navoi and Jami”, "Amir Temur”, “Manguberdi”, "Fergani”, "Gafur Gulam". The sculptor was able to prove himself as a master of modern sculpture, creating unique portraits of many historical figures in his work. Indeed, Ilkhom Jabborov is a mature artist who boldly entered contemporary monumental sculpture and created his great works in this area. [15]

One of these sculptors is Jaloliddin Mirtojiev, academician of the Academy of Arts of Uzbekistan, People's Artist of Uzbekistan. The sculptor Jaloliddin Mirtojiev is a sculptor who has achieved great success with his unique creations, his talent and skill with monumental sculptures erected in several foreign countries. This artist is a versatile artist and master of his craft, who works on both easel and monumental sculpture.

One of his first works created in the style of easel sculpture is the monument "Mother and Child". The work is dedicated to the memory of the participants and victims of the Great Patriotic War, in which the sculptor put forward the idea of patriotism. In addition, Jaloliddin Mirtojiev created a number of works on a variety of topics. In 1990, J. Mirtojiev created the image of the national hero "Temurmalik" in the style of smallsized bronze sculptures, in 1995 - "Rain", and in 2000 - "Bobur the Leader", dedicated to Zakhiriddin Muhammad Bobur. In the Surkhandarya region there is a monumental monument "Happy family", consisting of several figures, and in Tashkent, in the garden of the Museum of Kamoliddin Behzod, sculptures dedicated to the great artist Kamoliddin Bekhzod have been created.

J. Mirtojiev gradually began to create monumental sculpture. Throughout his entire career, he began to create works with an in-depth study of images on historical, national-patriotic themes. With his 
The American Journal of Social Science and Education Innovations (ISSN - 2689-100x)

VOLUME 04 ISSUE 01 Pages: 9-13

SJIF IMPACT FACTOR (2020: 5. 525) (2021: 5. 857)

OCLC - 1121105668 METADATA IF - 8.106

\section{Crossref}
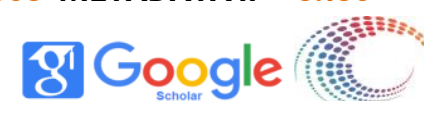

metapenta

(5) WorldCat"

Publisher: The USA Journals

monumental sculptures installed abroad, he made his weightless contribution to the popularization of Uzbek art throughout the world.

Among them are such monumental statues of Abdulla Kadiri, Temurmalik, a representative of the Temurid dynasty, the great commander and statesman Zakhiriddin Muhammad Babur, the great Uzbek intellectual, the writer Cholpon, statues of Alisher Navoi installed in the city of Tokyo in Japan and in Moscow in Russia, statues of Al-Fergani in Egypt and Azerbaijan, a monument to Kamoliddin Behzod in the city of Changchun, China, a statue of Ibn Sina in Kortrijk in Belgium and in the city of Riga in Latvia, a sculpture by the famous writer Gafur Gulam, at the entrance to the Park of Culture and Rest named after Gafur Gulam in the city of Tashkent. Among them, one can especially emphasize the monument to the beloved writer of the Uzbek people Zulfiya, created in 2008 and, finally, the monument "Oath to the Fatherland", erected in 2010 on the Square of Courage in the city of Tashkent.

One of the sculptors working in the field of easel sculpture and having his own style and character in his work is Azamat Khatamov. This artist has participated in several creative exhibitions with his magnificent works. Azamat Khatamov in his works refers mainly to the image of a woman, and he manages to reveal the graceful, beautiful and unique sides of the female figure. In the creation of his works, the master uses mainly bronze, stone and other similar materials. The works of Azamat Khatamov have a deep philosophical meaning from the point of view of compositional structure. [16]

During the years of independence A. Tukhtaev as an architect participated in the creation of a number of monumental monuments and sculptures. Among them are such magnificent works as the statue of Alisher Navai in the city of Navai (2001, sculptor A.
Rakhmatullaev), the "Goodness" monument - the Arch of good and noble aspirations (2006, sculptor R. Ermetov), the magnificent monumental statue "Family" in the city of Karshi (2006, sculptor R. Mirtojiev), the monumental sculpture "Ancient and Eternal Bukhara" (2010, sculptor I. Jabborov), and especially noteworthy is the monument to the First President of Uzbekistan I.A. Karimov in Tashkent I. (2010, sculptor I. Jabborov) [17.22-24].

\section{CONCLUSION}

In conclusion, it should be noted that the socio-political measures taken throughout the republic to appeal to history, awareness of national identity, promotion of the historical roots of the idea of national independence ensured the continuation of the traditions of monumental sculpture inherent in realism in modern Uzbek art. Works were created on topics such as the depiction of the images of our great ancestors, scientists and historical figures, their majestic statues, busts and frescoes. However, these processes were characterized not only by the restoration of the character and events of historical figures, but at the same time they influenced the emergence of new trends in the search for individual styles. In particular, when creating the image of historical figures in the works of Ilkhom Jabborov, Jaloliddin Mirtojiev, Kamol Jabborov, Azamat Khotamov, Rustam Yermetov and Kurban Norhozov, much attention was paid to the characters of historical figures in the style of majestic sculpture based on academic realism.

\section{REFERENCES}

1. Shavkat Mirziyoyev. Resolution of the President of the Republic of Uzbekistan №PP-3219 dated August 16, 2017 "On additional measures for the 
The American Journal of Social Science and Education Innovations (ISSN - 2689-100x)

VOLUME 04 ISSUE 01 Pages: 9-13

SJIF IMPACT FACTOR (2020: 5. 525) (2021: 5 . 857)

OCLC - 1121105668 METADATA IF - 8.106

Crossref doi gi Google

development and further improvement of the activities of the Academy of Arts of Uzbekistan".

2. Karimov. I. "High spirituality is an invincible force". Publishing house "Uzbekiston", 2008 P. 34-43.

3. Abdullaev. N. "History of Art of Uzbekistan". Tashkent 2007.

4. Khakimov. A. "Modern decorative plastics of the Republics of Central Asia". Fan. Academy of Sciences of the Republic of Uzbekistan.

5. Khakimov. A. "Art of Uzbekistan" Tashkent: 2001.

6. Okilova. K. "Sculpture of Uzbekistan". 2006.

7. Normatov N. "The sculptor and the symbol" (strokes for the portrait of the sculptor A. Khatamov), "Art" magazine 3/1999.

8. Ortiqov A. "THE IMPORTANCE OF THE ARTIST'S WORK IN CINEMA ART” European Science Review № 3-4/ 8-12

9. Yusupov A.A "Standars of beauty in modern painting" Actual problems of modern science, education and training/ № July 07.01/103-107

10. Yusupov A.A "FEATURES OF THEATER SPECTATOR INTERACTION” CURRENT RESEARCH JOURNAL OF HISTORY 2(11): /68-72.

11. Haydarova N. "SPECIAL EFFECTS IN MODERN UZBEK ANIMATED FILMS" European Science Review № 3-4 /20-24
12. Fadeeva T.V. "ENERGY IN ART AND THE PROCESS OF TEACHING OF CREATIVE DISCIPLINES." Science, technology and education № 3 (78)/53-57

13. Jalolova. G.M "DANTE ALIGERI'S "DIVINE COMEDY" WORK AND FILMS VISUAL ANALYSIS BASED ON THIS WORK" JournalNX- A Multidisciplinary Peer Reviewed Journal № 9/6466

14. Jalolova. G.M "ROLE OF FILM ARTISTS IN CINEMATOGRAPHY. HISTORY, LIFE AND CREATIVITY OF FILM ARTISTS IN UZBEK CINEMA" International Scientific Journal Theoretical \& Applied Science 28.09.2021/590-592,

15. www. Ilxom Djaddarov Uz "Old and eternal Bukhara" Article about Ilkhom Jabborov. 2010.

16. www. ru "Greats"

17. Akbar Hakimov is an art critic. Azamat Tukhtaev: architect of ideas.2021.San'at-3-son. P. 22-24. 